\title{
Quantitative HPLC Analysis of Sesquiterpene Lactones and Determination of Chemotypes in Eremanthus seidelii MacLeish \& Schumacher (Asteraceae)
}

\author{
Humberto T. Sakamoto ${ }^{a}$, Leonardo Gobbo-Neto ${ }^{b}$, Alberto J. Cavalheiro ${ }^{c}$, Norberto P. Lopes ${ }^{*, b}$ \\ and João L. C. Lopes ${ }^{*, b}$ \\ ${ }^{a}$ Departamento de Química, Faculdade de Filosofia, Ciências e Letras de Ribeirão Preto, Universidade de \\ São Paulo, 14040-901 Ribeirão Preto - SP, Brazil \\ ${ }^{b}$ Departamento de Física e Química, Faculdade de Ciências Farmacêuticas de Ribeirão Preto, Universidade de \\ São Paulo, 14040-903 Ribeirão Preto - SP, Brazil \\ ${ }^{c}$ Instituto de Química, Universidade Estadual Paulista, 14800-900 \\ Araraquara - SP, Brazil
}

\begin{abstract}
Eremanthus seidelii MacLeish \& Schumacher tem ocorrência restrita ao cerrado, em torno do reservatório de Furnas (MG), em habitats que vêm sendo seriamente deteriorados pela ação humana. A presente investigação fitoquímica mostrou, como metabólitos secundários majoritários das folhas de E. seidelii, as lactonas sesquiterpênicas (LS) 4/,5-diidro-2',3'-diidroxi-15-desoxigoiazensolídeo (1) e 4 $\beta$,5-diidro-1',2'-epoxi-eremantolídeo-C (2); uma metodologia foi desenvolvida em CLAE para sua análise quantitativa. A análise por CLAE mostrou que não há variações sazonais significativas nas concentrações de ambas LS. Não foram encontradas diferenças qualitativas nos perfis de LS nos indivíduos amostrados. Entretanto, há diferenças no perfil quantitativo entre os indivíduos analisados, apontando para a existência de três quimiotipos quantitativos desta espécie, com diferenças possivelmente originadas na atividade enzimática das enzimas que ciclizam uma LS tipo goiazensolídeo (1) em uma LS tipo eremantolídeo (2).
\end{abstract}

Eremanthus seidelii MacLeish \& Schumacher has a restricted occurrence to the Brazilian "cerrado" surrounding the Furnas (MG) reservoir, in environments that have been seriously damaged by human activity. The present phytochemical investigation reveals that the sesquiterpene lactones (SL) 4 $\beta, 5$-dihydro-2',3'-dihydroxy-15-desoxy-goyazensolide (1) and 4 $\beta, 5$ dihydro-1',2'-epoxy-eremantholide-C (2) are the major secondary metabolites in E. seidelii leaves, and an HPLC method was developed for their quantitative analysis. HPLC analysis showed no significant seasonal variation in the concentrations of both SL. No qualitative differences were found in the SL patterns of all individuals sampled. However, there is a different SL quantitative pattern among the plants analyzed, pointing to the existence of three quantitative chemotypes of this species, with differences possibly originating from the activity of the enzymes that cyclize the goyazensolide type SL (1) to a eremantholide type SL (2). seidelii

Keywords: HPLC, sesquiterpene lactones, chemotypes, populational variation, Eremanthus

\section{Introduction}

The genus Eremanthus Less (Asteraceae: Vernonieae) comprises 22 species that are restricted to the Brazilian "cerrado". ${ }^{1,2}$ Previous phytochemical investigations with this genus led to the isolation of flavonoids, triterpenes, poliacetylenes and revealed sesquiterpene lactones (SL) as the main secondary metabolites. ${ }^{3-9}$ Some of the SL

*e-mail: joaoluis@usp.br, npelopes@fcfrp.usp.br isolated from the Eremanthus genus posses important biological activities, ${ }^{3,6-8,10}$ like the antiproliferative effects on some cancer cell lines ${ }^{11}$ and the modulation of the inflammatory process in vitro, by inhibiting the NF- $\kappa \beta$ transcriptor factor. ${ }^{12}$

Seasonal, ${ }^{13-16}$ circadian $^{17-19}$ and populational ${ }^{20-24}$ variations in the content of almost all classes of secondary metabolites, including SL, ${ }^{25-29}$ were reported. The recognition of variations in secondary metabolite production can be helpful in chemotaxonomic studies, 
specially for the determination of qualitative and quantitative chemical markers that could be applied to establish chemotypes and as additional taxonomic characters for the definition of complex taxa. ${ }^{22,30,31}$ In this way, SL occurrence has been used as taxonomic support to determine the limits of the tribes and sub-tribes in Asteraceae, including the sub-tribe Lychnophorinae, in which Eremanthus belongs. ${ }^{1,32,33}$

Eremanthus seidelii MacLeish \& Schumacher has a restricted ocurrence to the "cerrado" surrounding the Furnas reservoir in southwestern Minas Gerais state, in microenvironments that have been seriously damaged by human activity. ${ }^{1,2}$ Previous phytochemical investigation of this species afforded SL of goyazensolide and eremantholide types. ${ }^{9}$ The lack of studies regarding possible temporal or intra-specific variations in E. seidelii secondary metabolism, as well as the lack of studies in this way with plants from the Brazilian "cerrado", led us to develop a method for the quantitative analysis of the major secondary metabolites of this plant.

\section{Experimental}

\section{Chemicals}

The solvents employed for isolation of standards were AR grade, and those used in HPLC and sample preparation were HPLC grade (Mallinckrodt). HPLC grade water $(18 \mathrm{~m} \Omega)$ was prepared using a Milli-Q system (Millipore). Coumarin used as the HPLC internal standard was from Merck.

\section{Equipment}

HPLC analysis was performed on a Shimadzu LC-6A apparatus with a UV detector SPD-6AV (set at $280 \mathrm{~nm}$ ) coupled with an auto injector (SIL-10ADvp, Shimadzu) or a Shimadzu LC-6AD apparatus with a Diode Array Detector (SPD-M10Avp, Shimadzu), coupled with an auto injector (SIL-10AF, Shimadzu), both using the software CLASS-VP 6.14. For quantitative analysis, a Spherisorb ODS-2 column ( $5 \mu \mathrm{m}, 4.6 / 250 \mathrm{~mm}$; Sigma-Aldrich) coupled with a guard-column (Supelguard $2 \mathrm{~cm}-$ Supelco) were used. For preparative HPLC a Shimpack ODS column (5 $\mu \mathrm{m}, 20 / 250 \mathrm{~mm}$; Shimadzu) was used.

\section{Plant material}

Plants from three populations of E. seidelii were identified by Prof. Dr. João Semir, UNICAMP, where voucher material were deposited (NPL 223, NPL 226 and
NPL 228; herbarium UEC). Population A: São João Batista do Glória - MG (NPL 223; S $20^{\circ} 37.540$ ', W 046 19.391'; altitude $900 \mathrm{~m}$ ); population B: Furnas - MG (NPL 228; S $20^{\circ}$ 42.107', W 046 17.336'; altitude $1090 \mathrm{~m}$ ) and population C: Furnas - MG (NPL 226; S $20^{\circ} 38.316^{\prime}$, W $046^{\circ} 15.318^{\prime}$; altitude $1010 \mathrm{~m}$ ). Ten plants in each population were randomly marked for collection.

For 25 months (April/2000 - April/2002), leaves of each marked plant were collected at 12:00 pm $( \pm 30 \mathrm{~min})$ in intervals of one month for seasonal studies. Every three months interval, starting on June/2000, plants from population $\mathbf{A}$ were also sampled at 12:00 pm, 4:00 pm, 9:00 pm, 2:00 am and 7:00 am ( $\pm 15 \mathrm{~min})$ for circadian analysis. All plant material was dried, as soon as possible, at $40{ }^{\circ} \mathrm{C}$ under forced ventilation for $48 \mathrm{~h}$, and then stored in a freezer.

\section{Isolation and identification of standards}

Milled leaves of E. seidelii (1080 g) were exhaustively extracted with ethanol by maceration. $50.0 \mathrm{~g}$ of the crude extract was suspended in $800 \mathrm{~mL}$ of hexane and filtered, affording $40.0 \mathrm{~g}$ of precipitate. $21.6 \mathrm{~g}$ of the precipitate were suspended in $500 \mathrm{~mL}$ of $\mathrm{H}_{2} \mathrm{O}$ and extracted with $n$ - $\mathrm{BuOH}(150 \mathrm{~mL} \times 3)$, yielding $13.6 \mathrm{~g}$ of $n-\mathrm{BuOH}$ fraction. A $4.0 \mathrm{~g}$ aliquot of the $n-\mathrm{BuOH}$ fraction was applied to a Sephadex LH-20 (Sigma, $400 \mathrm{~g}$ ) column using $\mathrm{MeOH}$ as eluent to afford 210 fractions $(13 \mathrm{~mL}$ each). These fractions were pooled by similarity in thin layer chromatography (TLC) on silica gel plates using $n-\mathrm{BuOH} /$ acetic acid/ $\mathrm{H}_{2} \mathrm{O}$ (60:15:25) as developing solvent and UV light and cerium sulfate in $\mathrm{H}_{2} \mathrm{SO}_{4}$ as detection system, yielding 14 sub-fractions.

Preparative HPLC analysis (isocratic elution with $\mathrm{MeOH} / \mathrm{H}_{2} \mathrm{O} 9: 1 ; \lambda=265 \mathrm{~nm}$; flow $9.5 \mathrm{~mL} / \mathrm{min}$ ) of the $n$-BuOH sub-fraction 45-48 (400 mg) afforded the 4 $\beta, 5-$ dihydro-1',2'-epoxy-eremantholide-C (2, Figure 1). The $n$-BuOH sub-fraction $37-40(756 \mathrm{mg})$ was submitted to CC in $40.0 \mathrm{~g}$ of polyamide (polyamide CC-6; Macherey-Nagel) eluted with mixtures of increasing polarity of hexane, $\mathrm{AcOEt}$ and $\mathrm{MeOH}$. The new fractions were pooled as described above and sub-fraction 13-14 was identified as 4 $\beta, 5$-dihydro-2',3'-dihydroxy-15-desoxy-goyazensolide (1, Figure 1). These two SL were identified by comparison of their ${ }^{1} \mathrm{H}$ and ${ }^{13} \mathrm{C}$ NMR and ESI-MS data with those previously published..$^{9,34}$

\section{Sample preparation for chromatographic analysis}

Powdered leaves of E. seidelii were weighed $(10 \mathrm{mg})$ in a glass vial and extracted in an ultra-sonic bath for 10 min with $1.5 \mathrm{~mL}$ of a solution of $\mathrm{MeOH} / \mathrm{H}_{2} \mathrm{O}$ (9:1) 
containing the internal standard coumarin $\left(50 \mu \mathrm{g} \mathrm{mL}^{-1}\right)$. $400 \mu \mathrm{L}$ of the extract was transferred to a centrifuge tube $(1.5 \mathrm{~mL})$, followed by the addition of $600 \mu \mathrm{L}$ of hexane. This mixture was stirred in a vortex and then centrifuged at $1200 \mathrm{~g}$ for $10 \mathrm{~min}$. An aliquot of $200 \mu \mathrm{L}$ was taken from hydro-alcoholic phase, filtered on a $0.45 \mu$ m cellulose acetate membrane and submitted to HPLC analysis, by injection of $20 \mu \mathrm{L}$.

\section{Analytical HPLC method}

Solvents: $\mathbf{A}=$ aqueous acetic acid $2 \%(\mathrm{v} / \mathrm{v}) ; \mathbf{B}=\mathrm{MeCN}$ with $2 \%$ acetic acid (v/v). Elution profile, 0 to $10 \mathrm{~min}: 10$ to 25\% B (linear gradient); 10 to 15 min: 25\% B (isocratic); 15 to $20 \mathrm{~min}$ : 25 to $45 \% \mathbf{B}$ (linear gradient); 20 to $25 \mathrm{~min}$ : $45 \%$ $\mathbf{B}$ (isocratic); 25 to $30 \mathrm{~min}$ : 45 to $80 \%$ B (linear gradient); 30 to $35 \mathrm{~min}: 80 \% \mathbf{B}$ (isocratic); 35 to $40 \mathrm{~min}$ : 80 to $10 \% \mathbf{B}$ (linear gradient); 40 to 50 min: $10 \% \mathbf{B}$ (isocratic). Flow rate:

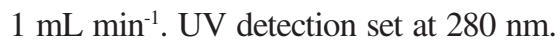

\section{Qualitative and quantitative determination}

The identity of the peaks relative to $\mathbf{1 , 2}$ or coumarin was established by comparison of retention time, UV spectra and co-injection of reference standards purified as described above. Furthermore, a relative retention time considering coumarin as internal reference was determined for each peak.

A quantitative analysis was done by the internal standard method, plotting calibration curves for $\mathbf{1}$ and $\mathbf{2}$ at concentrations of 1, 2, 5, 10, 20, 40 and $80 \mu \mathrm{g} \mathrm{mL}^{-1}$ in MeOH/ $\mathrm{H}_{2} \mathrm{O}$ 9:1. Each determination was carried out in triplicate. The purity of the standards was confirmed by HPLC analysis performed under the described chromatographic conditions and, for purposes of calculation, it was assumed that each standard was $100 \%$ pure.

For quantification of SL in E. seidelii leaves, chromatographic analyses were performed in duplicate and the SL content was estimated by a ratio of the two analysed peak areas averaged to the area of internal standard. Concentration is shown as percentage of SL in dry weight of leaves of E. seidelii.

\section{Results and Discussion}

This phytochemical investigation of E. seidelii leaves revealed the SL $4 \beta, 5$-dihydro-2',3'-dihydroxy-15desoxy-goyazensolide (1) and 4 $\beta, 5$-dihydro-1',2'-epoxyeremantholide-C (2) (Figure 1), both already isolated from this species and E. goyazensis, ${ }^{9}$ as its major secondary metabolites. Together, these SL can be responsible for up to $7.5 \%$ of the weight of the dry leaves

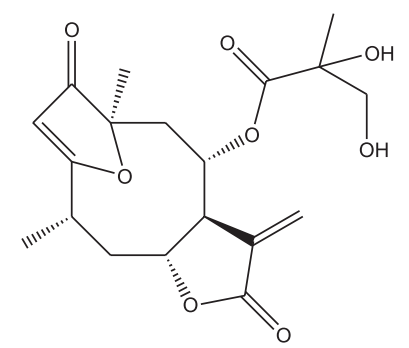

1

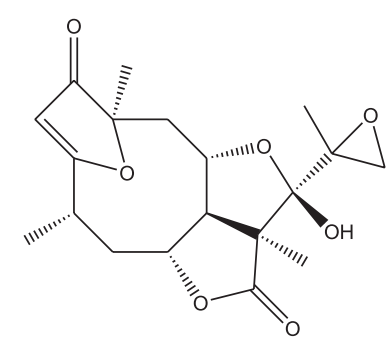

2
Figure 1. Chemical structures of the sesquiterpene lactones $4 \beta, 5$-dihydro2',3'-dihydroxy-15-desoxy-goyazensolide (1) and 4 $\beta, 5$-dihydro-1',2epoxy-eremantholide-C (2).

(data from plant 6, population A). This remarkable predominance, taken together with the SL utility as chemotaxonomic markers ${ }^{24,26,29,32,33}$ and biological activities $^{3,6-8,10-12}$ led us to develop the present HPLC method for their quantification.

\section{HPLC method}

Analysis carried out in triplicate with three consecutive extractions of the same material (powdered leaves of $E$. seidelii) revealed that $95.2 \%$ of $\mathbf{1}$ and $97.5 \%$ of $\mathbf{2}$ were extracted in the first one, which led us to use the one step extraction procedure described. The overall recovery of the compounds using the method of extraction and determination described was $97 \%$ for $\mathbf{1}$ and $98 \%$ for $\mathbf{2}$, and were based on 5 extractions (addition of 4 different concentrations of $\mathbf{1}$ and $\mathbf{2}$ and a control without addition of SL) done using powdered leaves of E. glomerulatus, a similar species lacking these two compounds, as matrix.

Calibration curves were made by plotting the ratio of SL peak areas to the area of coumarin as internal standard versus concentrations of each SL, and good linearity was obtained with the standard solutions of $\mathbf{1}$ and $\mathbf{2}$ in concentrations between $1-80 \mu \mathrm{g} \mathrm{mL}^{-1}$. The regression equations for $\mathbf{1}$ and 2 were, respectively, $\mathrm{y}=0.6144 \mathrm{x}+0.0258(\mathrm{r}=0.9991)$ and $\mathrm{y}=0.8630 \mathrm{x}+0.0327(\mathrm{r}=0.9992)$. The retention times in the system developed were $26.28 \mathrm{~min}$ for $\mathbf{1}, 24.87 \mathrm{~min}$ for $\mathbf{2}$ and $23.25 \mathrm{~min}$ for the coumarin internal standard (Figure 2).

The HPLC method developed was carefully validated. For the highest concentration the accuracy for both SL was $97.7 \%$. The relative standard deviation obtained from nine analyses performed on different days was $2.05 \%$ for $\mathbf{1}$ and $2.31 \%$ for $\mathbf{2}$, which gives a very high level of reproducibility. Extracts were also analyzed immediately and $24 \mathrm{~h}$ after their acquisition, and no significant differences were detected in peak areas. The limit of detection (signal-to-noise ratio of 3:1) was 0.30 and 0.22 $\mu \mathrm{g} \mathrm{mL}^{-1}$ for $\mathbf{1}$ and $\mathbf{2}$ respectively. The maximum limit of quantification for the detector and UV wavelength 


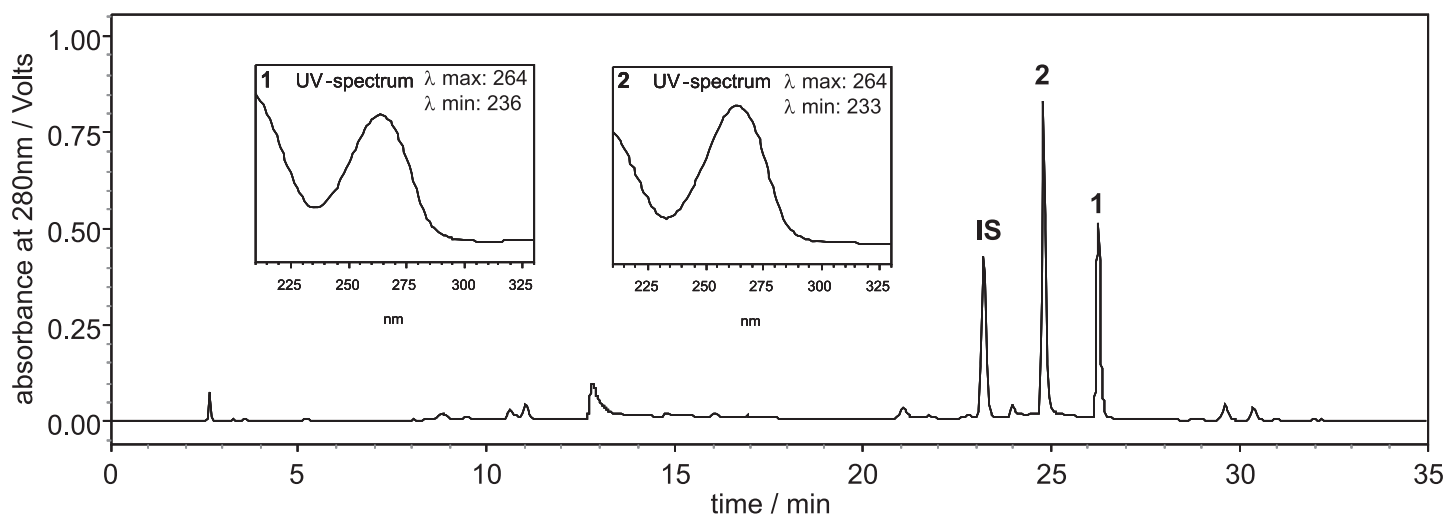

Figure 2. Chromatogram obtained for individual 5 from population A with the described method. Retention times are 26.28 min for 4 $3,5-$ dihydro-2',3'dihydroxy-15-desoxy-goyazensolide (1), $24.87 \mathrm{~min}$ for 4 $\beta$,5-dihydro-1',2-epoxy-eremantholide-C (2) and 23.25 min for the internal standard coumarin (IS).

employed was $422.0 \mu \mathrm{g} \mathrm{mL}^{-1}$ for $\mathbf{1}$ and $449.3 \mu \mathrm{g} \mathrm{mL}^{-1}$ for 2. Extracts were also done with samples stored for up to one year to evaluate their stability. No significant alteration in concentrations were found in samples stored for up to 11 months. The largest difference detected was $1.9 \%$ for leaves stored for one year, which shows good stability during storage.

\section{Analysis of E. seidelii leaves}

No qualitative differences were found in the SL patterns of all plants sampled. However, significant differences were found in the quantitative proportions of the main compounds (SL $\mathbf{1}$ and 2).

The concentrations of $\mathbf{1}$ and $\mathbf{2}$ in leaves of E. seidelii obtained for each individual in samples collected at the same time and day (19/March/2001, 12:00 pm $\pm 30 \mathrm{~min}$, Table 1) led us to group the studied individuals in three clusters with different ratios of compounds $\mathbf{1}$ and $\mathbf{2}$.

Table 1. Sesquiterpene lactone concentrations in leaves of the 30 Eremanthus seidelii individuals sampled in 19/March/2001 at 12:00pm \pm $30 \mathrm{~min}$

Sesquiterpene lactones concentration in Eremanthus seideli (\% per leaf dry weight)

SL 1 = 4 $\beta$,5-dihydro-2',3'-dihydroxy-15-desoxy-goyazensolide SL 2 = 4 $\beta, 5$-dihydro-1',2-epoxy-eremantholide-C

\begin{tabular}{ccccccc}
\hline population & \multicolumn{2}{c}{ A } & \multicolumn{2}{c}{ B } & \multicolumn{2}{c}{ C } \\
\hline plant & SL 1 & SL 2 & SL 1 & SL 2 & SL 1 & SL 2 \\
\hline 1 & 3.61 & 1.39 & 2.56 & 1.20 & 1.83 & 1.19 \\
2 & 1.85 & 2.80 & 2.77 & 0.14 & 2.50 & 0.32 \\
3 & 2.96 & 1.22 & 2.63 & 0.22 & 2.53 & 0.26 \\
4 & 0.58 & 2.72 & 2.53 & 0.19 & 2.68 & 0.35 \\
5 & 2.22 & 1.39 & 2.03 & 0.49 & 2.03 & 0.29 \\
6 & 5.79 & 1.72 & 2.22 & 0.91 & 1.95 & 0.17 \\
7 & 4.32 & 1.01 & 2.93 & 0.02 & 3.27 & 0.15 \\
8 & 2.79 & 0.55 & 2.66 & 0.07 & 2.05 & 0.13 \\
9 & 3.35 & 1.26 & 2.47 & 0.13 & 2.36 & 0.36 \\
10 & 4.39 & 1.53 & 2.53 & 0.38 & 2.05 & 0.79 \\
\hline
\end{tabular}

HPLC analysis carried out with plants selected to represent each of these three clusters, showed no significant seasonal variation in the concentration of $\mathbf{1}$ and $\mathbf{2}$ in none of them over the two years sampled (Figure 3). Individuals analyzed for seasonal variation were: 1,2, 4, 5 and 8 from population $\mathbf{A} ; 1,3$ and 7 from population $\mathbf{B}$; and 1, 3 and 7 from population $\mathbf{C}$. Furthermore, SL concentration in leaves of $E$. seidelii showed no significant correlation with the plant stem diameter or height, which were proposed as variables indicatives of the age of the plants. It is well known that in some tribes of Asteraceae, including Vernonieae and Heliantheae amongst others, SL are predominantly (if not
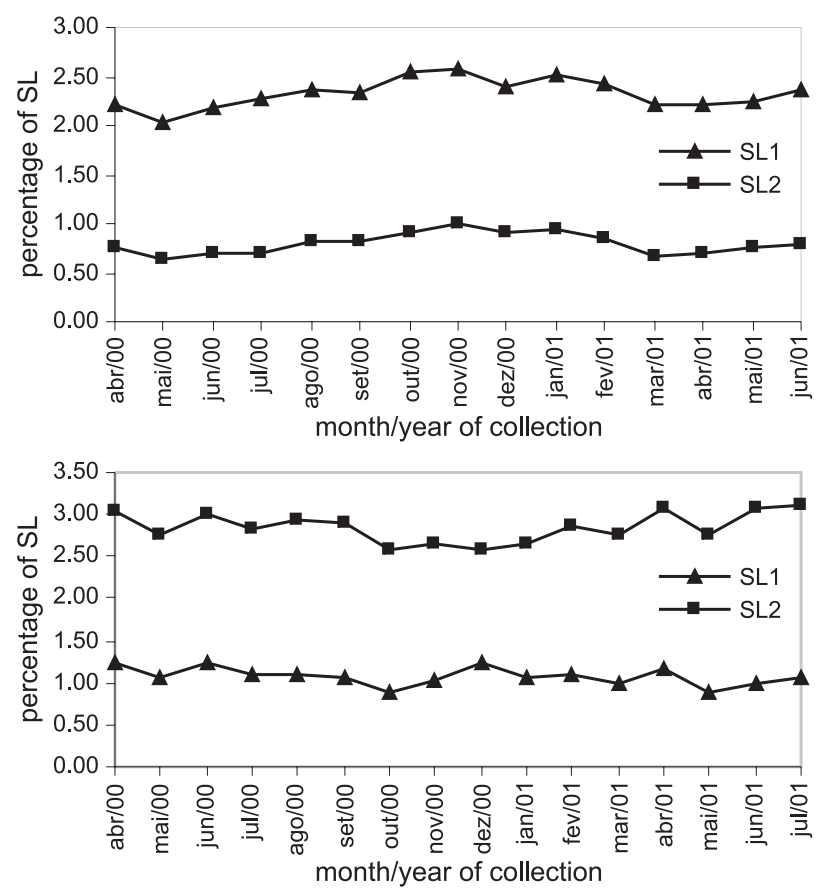

Figure 3. Examples of seasonal quantitative analyses of individuals with predominance of the goyazensolide type sesquiterpene lactone ( $4 \beta, 5$ dihydro-2',3'-dihydroxy-15-desoxy-goyazensolide, SL1, graph in top) and eremantholide type sesquiterpene lactone (4 $\beta, 5$-dihydro-1',2-epoxyeremantholide-C, SL2, bottom). 
exclusively) produced in glandular trichomes, which biosynthetic capacity is finished before leaves are expanded..$^{35}$ Thus, no circadian variation could be expected for these metabolites. Since the major secondary metabolites found in E. seidelii are SL, no analyses were carried out with samples collected previously for circadian studies.

Thus, any influence of environmental or developmental factors on the contents of $\mathbf{1}$ and $\mathbf{2}$ were excluded by the facts that neighboring trees can belong to different clusters, and that there are no seasonal variations in SL concentrations. Additionally, 1 (a goyazensolide type SL) is a biosynthetic precursor for $\mathbf{2}$ (a eremantholide type $\mathrm{SL}){ }^{3}$ which reveals genetic conditions to produce both $\mathrm{SL}$ in the plants studied. Therefore, the difference possibly remains in a differential activity of the enzymes that cyclisation 1 to 2 . These significant differences in the levels of biosynthetically related SL, taken together with the valuable property of SL as chemotaxonomic markers ${ }^{24,26,29,32,33}$ and the fact that $\mathbf{1}$ and $\mathbf{2}$ are the main constituents from the secondary chemistry in leaves of $E$. seidelii, lead us to propose the following quantitative chemotypes: (i) plants in this cluster are the only ones that present $\mathbf{2}$ in higher concentrations than $\mathbf{1}$. In fact, individuals in this cluster present the highest concentrations of $\mathbf{2}$ (more than $2.7 \%$ of the dried leaf weight in the plants studied) and the lowest concentrations of $\mathbf{1}$ (below $1.7 \%$ in the plants studied). Individuals 2 and 4 from population $\mathbf{A}$, which corresponds to $6.7 \%$ of the plants studied, represent this chemotype, denominated high $E$ for its high relative contents of the Eremantholide type SL 2; (ii) in the other extreme are grouped individuals with very low relative contents of $\mathbf{2}$, showing a ratio between $\mathbf{1}$ and $\mathbf{2}$ above 10. Individuals in this cluster show intermediate concentrations of $\mathbf{1}$ (between 1.9 and 3.3\% in the plants studied) and the lowest concentrations of $\mathbf{2}$ (below $0.2 \%$ in the plants studied). Plants 2, 3, 4, 7, 8 and 9 from population $\mathbf{B}$ and plants 6, 7 and 8 from population C (in total $30.0 \%$ of the plants analyzed) are representative of this chemotype denominated low E, for its low relative contents of the Eremantholide type SL 2; (iii) this last cluster is the largest one comprising plants that present an intermediate ratio of compounds $\mathbf{1}$ and $\mathbf{2}$ (between 1.5 and 10). The plants not included in the clusters above (which represents $63.3 \%$ of the individuals analyzed) form this chemotype denominated medium GE, due to the intermediate contents of both SL.

Similarly, quantitative chemotypes based on relative concentrations of biosynthetically related SL were, for example, established for Artemisia annи ${ }^{29}$ and Artemisia herba-alba. ${ }^{22}$

\section{Acknowledgments}

This work was supported by FAPESP, CAPES and CNPq. The authors acknowledge Prof. Dr. João Semir (Departamento de Morfologia e Sistemática Vegetal, Instituto de Biologia da Universidade Estadual de Campinas) for the plant identification and Dr Paul Gates (School of Chemistry, University of Bristol, UK) for the English language revision.

\section{References}

1. Robinson, H.; Smithsonian Contr. Bot. 1999, 89.

2. MacLeish, N. F. F.; Ann. Mo. Bot. Gard. 1987, 74, 265.

3. Le Quesne, P. W.; Levery, T. B.; Menachery, M. D.; Brennan, T. F.; Raffauf, R. F.; J. Chem. Soc., Perkin Trans. 1 1978, 1572.

4. Lunardello, M. A.; Tomaz, J. C.; Vichnewski, W.; Lopes, J. L. C.; Gutierrez, A. B.; Diaz, J. G.; Herz, W.; J. Braz. Chem. Soc. 1995, 6, 307.

5. Mauro, M. R. V.; Tucci, A. M.; Nasi, T.; Vichnewski, W.; Lopes, J. L.; Diaz, J. G.; Herz, W.; J. Braz. Chem. Soc. 1993, 4, 30.

6. Raffauf, R. F.; Huang, P. C.; Le-Quesne, P. W.; Levery, S. B.; Brennan, T. F.; J. Am. Chem. Soc. 1975, 97, 6884.

7. Vichnewski, W.; Gilbert, B.; Phytochemistry 1972, 11, 2563.

8. Vichnewski, W.; Sarti, S. J.; Gilbert, B.; Herz, W.; Phytochemistry 1976, 15, 191.

9. Vichnewski, W.; Takahashi, A. M.; Nasi, A. M. T. T.; Gonçalves, D. C. R.; Dias, D. A.; Lopes, J. N. C.; Goedken, V. L.; Gutiérrez, A. B.; Herz, W.; Phytochemistry 1989, 28, 1441.

10. Picman, A. K.; Biochem. Syst. Ecol. 1986, 14, 255.

11. Santos, P. A.; Amarante, M. F. C.; Pereira, A. M. S.; Bertoni, B.; França, S. C.; Pessoa, C.; Moraes, M. O.; Costa-Lotufo, L. V.; Pereira, M. R. P.; Lopes, N. P.; Chem. Pharm. Bull. 2004, $52,1433$.

12. Rüngeler, P.; Castro, V.; Mora, G.; Gören, N.; Vichnewski, W.; Pahl, H. L.; Merfort, I.; Schmidt, T. J.; Bioorg. Med. Chem. 1999, 7, 2343.

13. Agerbirk, N.; Olsen, C. E.; Nielsen, J. K.; Phytochemistry 2001, $58,91$.

14. Angelopoulou, D.; Demetzos, C.; Perdetzoglou, D.; Biochem. Syst. Ecol. 2002, 30, 189.

15. Menkovik, N.; Šavikin-Fodulovi, K.; Savin, K.; Planta Med. 2000, 66, 178.

16. Wilt, F. M.; Miller, G. C.; Biochem. Syst. Ecol. 1992, $20,53$.

17. Høgedal, B. D.; Mølgaard, P.; Biochem. Syst. Ecol. 2000, 28, 949.

18. Itenov, K.; Mølgaard, P.; Nyman, U.; Phytochemistry 1999, $52,1229$.

19. Lopes, N. P.; Kato, M. J.; Andrade, E. H. A.; Maia, J. G. S.; Yoshida, M.; Phytochemistry 1997, 46, 689.

20. Chaves, N; Escudero, J. C.; Gutiérrez-Merino, C.; Biochem. Syst. Ecol. 1997, 25, 429. 
21. Feuerstein, I.; Müller, D.; Hobert, K.; Danin, A.; Segal, R.; Phytochemistry 1986, 25, 2343.

22. Mabry, T. J.; Pure Appl. Chem. 1973, 34, 377.

23. Nehme, C. J.; Moraes, P. L. R.; Cavalheiro, A. J.; Biochem. Syst. Ecol. 2002, 30, 613.

24. Segal, R.; Feuerstein, I.; Danin, A.; Biochem. Syst. Ecol. 1987, $15,411$.

25. Passreiter, C. M.; Aldana, B. E. M.; Planta Med. 1998, 64, 427.

26. Picman, A. K.; Towers, G. H. N.; Biochem. Syst. Ecol. 1982, 10,145 .

27. Schmidt, T. J.; Bomme, U.; Alfermann, A. W.; Planta Med. 1998, 64, 268.

28. Zidorn, C.; Stuppner, H.; Taxon 2001, 50, 115.
29. Wallaart, T. E.; Pras, N.; Beekman, A. C.; Quax, W. J.; Planta Med. 2000, 66, 57.

30. Williams, C. A.; Demissie, A.; Harborne, J. B.; Biochem. Syst. Ecol. 1983, 19, 81.

31. Wilt, F. M.; Geddes, J. D.; Tamma, R. V.; Miller, G. C.; Everett, R. L.; Biochem. Syst. Ecol. 1992, 20, 41.

32. Seaman, F. C.; Bot. Rev. 1982, 48, 121.

33. Zdero, C.; Bohlmann, F.; Plant Syst. Evol. 1990, 171, 1.

34. Crotti, A. E. M.; Lopes, J. L. C.; Lopes, N. P.; J. Mass Spectrom. 2005, 40, 1030.

35. Spring, O.; Bienert, U.; J. Plant Physiol. 1987, 130, 441.

Received: May 20, 2005

Published on the web: November 9, 2005

FAPESP helped in meeting the publication costs of this article. 